\title{
Research on Integration and Incentive of Grass-Roots Employees in Urban Hotels
}

\author{
Mengyao Zhang ${ }^{1,}$ a, Fengzhi Zhang ${ }^{1, b}{ }^{~}{ }^{*}$, Jianyi Tang 2, c \\ 1. School of Management, Shandong Women's University, Jinan, China \\ 2. Shandong Women's University, Jinan, China \\ a myao825@foxmail.com, b, * sdjjzfz@163.com, c1272332983@QQ.com
}

\begin{abstract}
With the rapid development of economy and society, talent competition has become an important link in the development of the hotel industry. In order to provide customers with high-quality services and attract high-quality talents, enterprises must improve the incentive mechanism of grassroots employees of urban hotels. This should not only attract customers in hardware facilities, but also strengthen the management and rational utilization of human resources. An effective and complete talent incentive mechanism is conducive to avoiding the loss of excellent talents in the hotel and the long-term development of the enterprise. This paper mainly takes urban hotels as the research point, based on the two-factor theory, and through the method of questionnaire survey, focuses on the problems existing in the incentive of grass-roots employees and how to build and improve the incentive system, so as to provide reference for the construction of enterprise incentive system. Only by establishing a scientific and perfect incentive mechanism, improving the performance salary and welfare system, and establishing and improving the training and promotion mechanism, can enterprises win a lasting competitive advantage in the market.
\end{abstract}

Keywords: Urban Hotel; Grassroots Employees; Excitation.

\section{Introduction}

With the rapid development of economy and society, the competition in the hotel industry is constantly rising. The high turnover rate of hotel grass-roots employees and low work enthusiasm have become the main problems. The hotel industry belongs to the service industry, and the working attitude, ability and behavior of hotel grass-roots employees will directly determine the service level of the hotel, and will affect customers' emotions and consumption decisions. The changing internal and external environment faced by urban hotels has gradually slowed down the development of hotels. Although the hardware facilities of the hotel are perfect, there are still some problems for grass-roots employees, such as low quality, difficult integration, lack of work passion and vitality and so on. Therefore, the hotel urgently needs to solve the incentive mechanism of grass-roots employees and establish a scientific human resources incentive system, so as to improve the job satisfaction and enthusiasm of grass-roots employees and enhance the turnover of the hotel.

\section{Analysis on Incentive Problems and Causes of Grass-Roots Employees in Urban Hotels}

\subsection{The Incentive Concept of the Hotel is Backward}

The turnover rate of personnel in the hotel industry is relatively high. Managers believe that the education level of grass-roots employees is low, but these people are the main force of hotel services, ignoring the importance of incentive to retain grass-roots employees. Moreover, the competition in the hotel industry is fierce. The management attaches importance to the profitability of the hotel. All aspects of the hotel need expenditure, and the cost is not small. As a hotel, the training of grass-roots employees requires a lot of human, material and financial resources, and the turnover rate of grassroots employees is very high, so most hotels will give up in-depth training. The grass-roots employees also need material rewards such as salary and welfare, promotion opportunities and development 
space, but the form of the hotel incentive mechanism is too single, and the training content of the hotel is not targeted, resulting in a series of problems in the hotel incentive mechanism.

\subsection{Lack of Scientific Incentive Mechanism}

In the incentive mechanism of grass-roots employees, the hotel has not well combined material incentive with spiritual incentive. Grass roots employees lack a sense of participation and belonging, and have been drifting away from the management of the hotel. It leads to a lack of sense of responsibility and inability to bear their own responsibility. During service, the attitude is vulnerable to emotional fluctuations, especially customer complaints, which makes the emotional fluctuations of grass-roots employees greater, and the work enthusiasm continues to decrease, resulting in a vicious circle. The negative incentive of the hotel will also affect the job satisfaction and work enthusiasm of grass-roots employees. When grass-roots employees perform well, they will not be rewarded and praised. However, when they encounter problems at work, they will be criticized by managers, and the negative emotions of grass-roots employees will increase, resulting in the failure to improve the service quality of the hotel.

\subsection{Lack of Respect and Humanistic Care}

Urban hotels pay more attention to the construction of hardware facilities, and there are great defects in the hotel environmental incentive system. There is no real care for grass-roots employees and less basic respect for employees. It only takes grass-roots employees as a tool to seek benefits, and there is no real people-oriented management model. If the hotel does not change this management mode and implements the people-oriented management mode to care about grass-roots employees, it will reduce the satisfaction of grass-roots employees and finally increase the turnover rate of grassroots employees.

\section{Research on Incentive Improvement Countermeasures for Grass-Roots Employees of Urban Hotels}

\subsection{Improve the Welfare Incentive System}

The existing welfare structure of the hotel should be more diversified. The hotel should increase the transparency of the welfare system. For the welfare system of the hotel, the wishes of grass-roots employees should be sought to make grass-roots employees better understand the welfare system. The setting of the welfare system should be concise and easy to understand. Each item of income and additional benefits should be explained well, so that grass-roots employees can see the importance of the hotel on welfare. In addition, the hotel can increase the collective activities of some grass-roots employees, provide rich and colorful cultural facilities and enrich the cultural and entertainment life of grass-roots employees. Appropriately increasing the leave of grass-roots employees can provide marriage leave, maternity leave, funeral leave, etc. for grass-roots employees of the hotel, and appropriately increase the number of days of paid leave according to the qualifications and positions of grass-roots employees. For grass-roots employees with outstanding performance, some tourism incentives can be provided as an incentive means for grass-roots employees of the hotel.

\subsection{Improve the Performance Evaluation System}

The performance evaluation system of the hotel mainly includes the evaluation of grass-roots employees' work performance, work plan, work ability and attitude, and department satisfaction. Firstly, the hotel manager shall set the performance and work indicators of the grass-roots employees according to the work posts of the grass-roots employees and the strategic objectives of the hotel, regularly measure the completion of various work of the grass-roots employees, formulate corresponding performance appraisal standards, and review the completion quality of each work of the grass-roots employees of the hotel, so as to meet the qualitative standards specified by the hotel. 
Secondly, assess the ability and attitude of grass-roots employees. The attitude of grass-roots employees determines the quality of their services. The management should assess the ideology and work style of grass-roots employees every year to check whether they have the ability to complete basic work. Finally, through questionnaires or interviews, we can dynamically measure the work of their grass-roots employees, constantly assess the performance of each department in the plan, and feed back the satisfaction of each department to the superior.

\subsection{Strengthen Respect and Humanistic Care for Grass-Roots Employees}

The hotel should adhere to the "people-oriented" incentive, fully care for and respect every employee, actively safeguard the interests of employees, and create a good working atmosphere for employees, so that they have a sense of belonging. When there is a dispute between customers and employees, the hotel must handle it carefully, understand the truth in many aspects, not only maintain the customer's face, but also do not hurt the employee's self-esteem. To enable employees to participate in the management of the hotel, the management should listen to employees' opinions and ideas, encourage and praise good opinions and ideas, and let employees feel the importance attached to them by the senior management of the hotel. The hotel should also give employees a good working environment and welfare, pay more attention to employees in life, organize more group construction activities at ordinary times, and enrich the spiritual and cultural life of grass-roots employees. It should not only achieve material incentives, but also encourage employees in spiritual and cultural aspects.

\section{Conclusion}

Under the guidance of relevant incentive theories, a scientific and perfect incentive system can promote the growth of hotels and is an important part of the hotel competition system. Combined with the current incentive situation of grass-roots employees in the hotel industry, this paper discusses the problems and Countermeasures of grass-roots employee incentive. This paper holds that urban hotels should establish a complete and scientific incentive system suitable for the development of the hotel, which can be carried out from three aspects: improving the hotel's salary and welfare system, improving the performance evaluation system, and strengthening the respect and care for employees. According to the actual situation of the hotel, the grass-roots employees are encouraged from the root. Only a scientific and reasonable incentive system can make the hotel go further.

\section{References}

[1] Wang Junchao On the incentive mechanism of hotel employees in China [J] Inner Mongolia Science and technology and economy, 2016 (15): 22.

[2] Liu Xiao, Tong Xiaoyan Research on Incentive of hotel grass-roots employees based on hierarchy of needs [J] Modern commerce and industry, 2013 (15): 102-103.

[3] Zhuang yanmiao Research on employee incentive of economic chain hotels [J] China market, 2016 (40): 60.

[4] Wang linli Research on the problems and Countermeasures of grass-roots employee incentive in H Hotel [D] Henan University of science and technology, 2016.

[5] Li Jiaming Research on employee incentive mechanism of J China tobacco company based on two factor theory [D] Nanchang University, 2018.

[6] Jiang Lijuan Problems and root causes of hotel knowledge employee incentive [J] Hubei Vocational College of Finance and taxation, 2018 (2): 65-66. 